\title{
Management, Treatment and Disposal of Wastewater (Sewage) Plan at Kuwait Oil Company (KOC)
}

\author{
Khulood Yousef, Saud Al-Mutairy, and Fouzy Haitham
}

\begin{abstract}
This paper presented and discussed the management, treatment and disposal of wastewater plan (sewage) at KOC to maintain the Kuwaiti Environment Eco-System clean and healthy.

The treated wastewater has been suggested for KOC irrigation, landscaping purposes and conserving the freshwater.

We comply with KEPA develops the methodologies, standards and KOC procedure for management of wastewater discharge.

The sewage treated in three sewage treatment plants (STP) within KOC operational areas. Each plant having a capacity of $300 \mathrm{~m}^{3} /$ day.

In this study, the physical, chemical and biological characteristic of the wastewater samples were studied and continuously analyses before feeding to the plant and after the treatment.

The benefits and values of wastewater treatment at KOC shows as following:

Reduce pollution due to transportation

Reduce Economic Expenses

Reduce the fuel usage

Reduce the demand of freshwater for irrigation in KOC etc.

Reduce the greenhouse gas emission.
\end{abstract}

Index Terms-KOC procedure, KEPA regulation, wastewater, treatment plant, environmental control, treatment process.

\section{INTRODUCTION}

Kuwait Oil Company (KOC) established in 1934, is one of the largest oil exporter in the world, headquartered in Ahmadi, Kuwait. The Company activities had extended to include exploration operations, on-shore and offshore surveys, drilling of test wells, and developing of producing fields as well as crude and natural gas exploration.

HSE South \& East Kuwait (S\&EK) Directorate identified the need for the Sewage Treatment Plant - STPs back in 2009 and formed a task force team to tackle the issue. Furthermore, HSE (S\&EK) Team took the initiative to collect and compile the sewage generation data (as well as the expected increase in sewage load in the future) for all KOC operational areas. Based on existing sewage data and the expected increase in Company's manpower and hence sewage generation, it was recommended to have three nos. of STPs to handle the sewage generated from all KOC operational areas. HSE (S\&EK) Team developed subsequently technical

Manuscript received August 11, 2014; revised October 15, 2014

The authors are with the Kuwait Oil Company, Kuwait (corresponding author: Saud Al-Mutairy; e-mail: khyousef@kockw.com, SAMutairi@kockw.com, HFouzy@kockw.com). specifications for the STPs.

This Wastewater (sewage) Management Plan (WWMP) forms part of a range of activities in addressing the management of wastewater within(S\&EK) Directorate. It serves to fulfill KOC obligations with respect to Kuwait Environment Public Authority (K-EPA) regulations whilst outlining the priorities and strategies HSE-S\&EK must implement in order to reduce the impact of wastewater on health and the environment [1]-[3] (see Fig. 1).

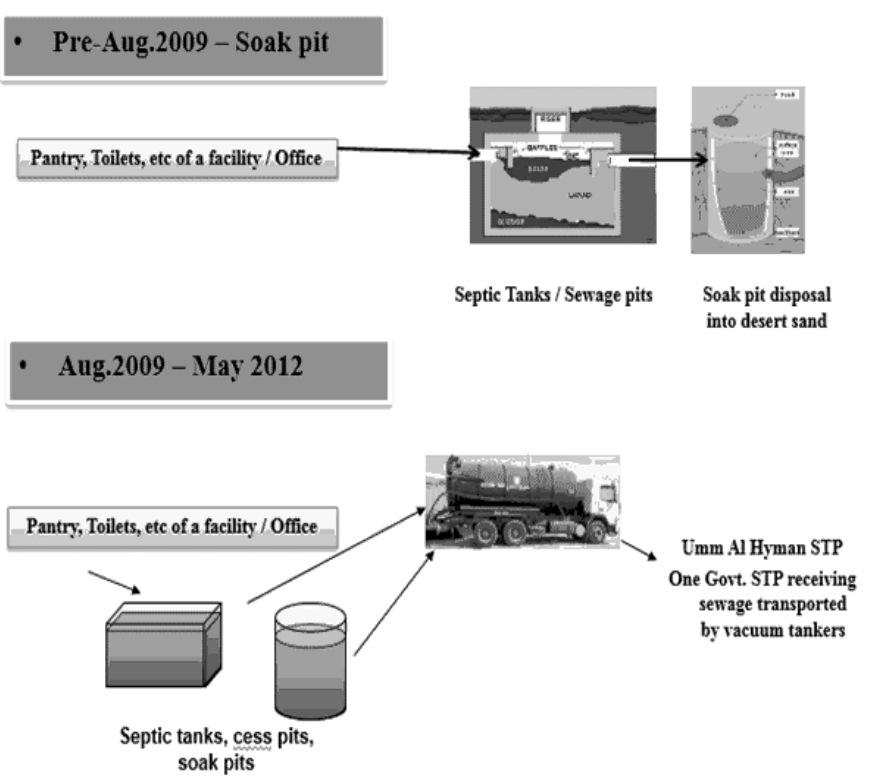

Fig. 1. Historical perspective - Sewage collection \& disposal at KOC facilities.

Sewage treatment is the process of removing the contaminants from sewage to produce liquid and solid suitable for discharge to the environment or for reuse. It is a form of waste management. Wastewater treatment system used to treat sewage close to where it is created. Sewage water is a complex matrix, with many distinctive chemical characteristics. These include high concentrations of BOD, COD, high conductivity (due to high dissolved solids), with $\mathrm{pH}$ typically ranging between 7 and 8 . Operating conditions and process carried out influence the amount and characteristics of the products and waste formed. The wastewater varies both quality and characteristics from the KOC facilities [3], [4].

Wastewater treatment plants are commonly used as efficient means of wastewater treatment relying on little technology and minimal, albeit regular maintenance.

Advances in scientific knowledge have changed pollution control, because there is a connection of environmental contamination with the ability to measure it. With greater understanding of the impact of wastewater on the environment and more sophisticated analytical methods, 
advanced treatment is becoming more common (Lofrano \& Brown, 2010).

\section{MATERIAL AND METHODS}

KOC decided to establish its own Sewage Treatment Plants (STP) to treat all the sewage at KOC Operational Areas (S\&EK, NK, WK, NTF \& STF, COCC, VOIPD offices, etc.).

The STP's are located at:

- Burgan (South Kuwait)

- Magwa (East Kuwait)

- Umm Al-Aish Oasis (North Kuwait)

Awarded contractor under contract (Drainage \& Sewage Services for Company's Operational Areas) for all KOC facilities collected the Sewage (see Fig. 2) as per the Scope of the contract as followed:

- Collection \& Disposal of Sewage
- Implementing Sewage Treatment Plant

- Pictorial walkthrough a KOC STP

\section{A. Highlights of Sewage Treatment Plants (STP's)}

- The 3 STP's are identical and designed to treat 300 cubic meters of sewage per day.

- Facilities are operational $24 \times 7$ days.

- Currently no sewage from the Company's operational areas is transported outside the Company for treatment/ disposal.

- Treated water from the STPs is meeting Kuwait Environmental public authority K-EPA standards (Appendix 15) and is transported through water tankers / pipe to various locations within the Company for use in horticulture.

- The STP's also receive and treat sewage from contractor's site offices and drilling rigs within the company's operational areas

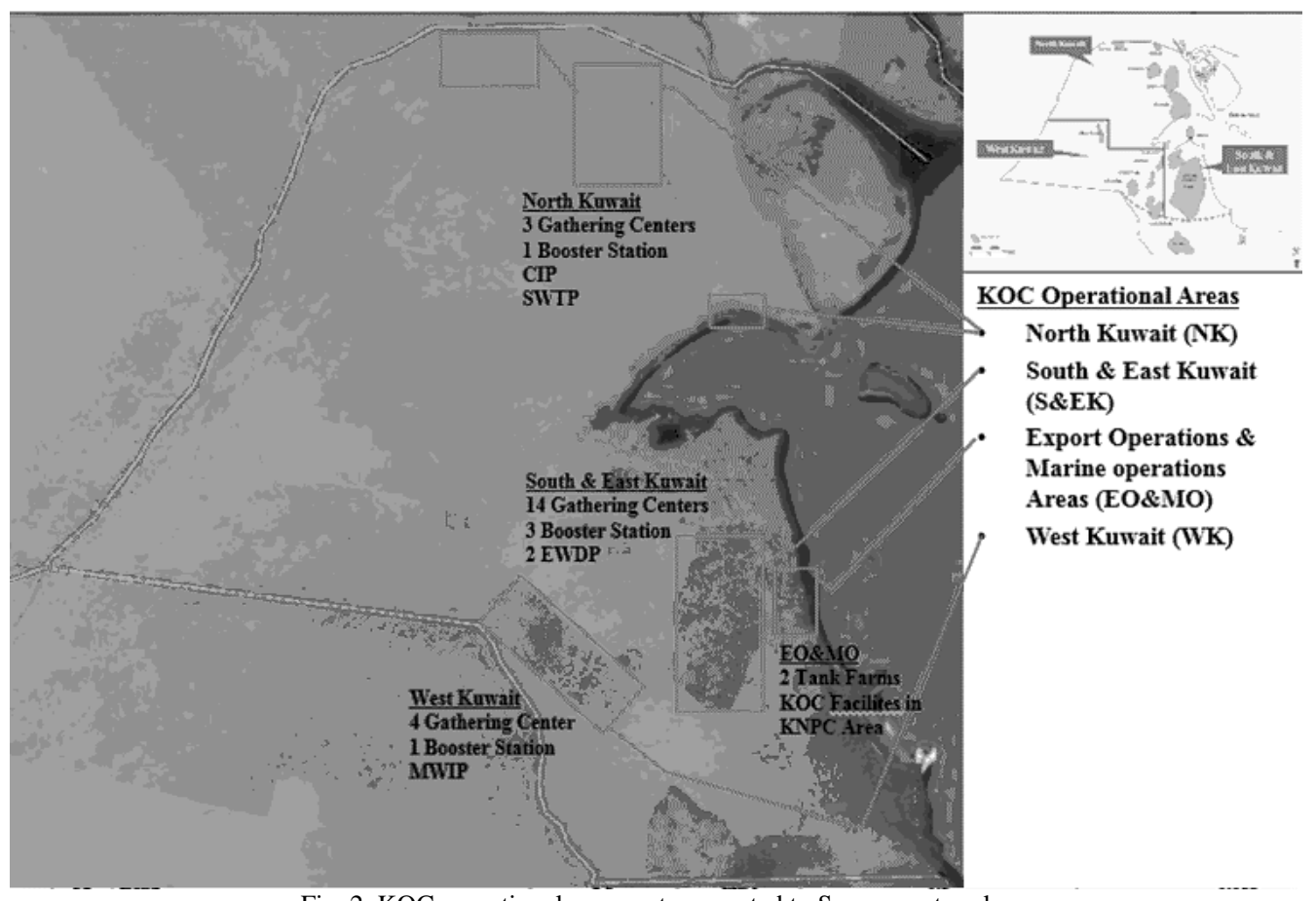

Fig. 2. KOC operational areas not connected to Sewage network.

\section{B. Management of Wastewater Treatment and Control}

STPs are projected to treat all sewage water generated at the company's operational sites including contractor's offices and from drilling rigs located within companies' operational areas.

The sewage enters the system through the screen, which removes all parts bigger that $3 \mathrm{~mm}$. It then stays in equalization tank and is pumped by timer controlled pumps into the Dissolved Air Concentration (DAC) system, where most of the pollution is removed. Some water is now returned to the equalization tank and the rest is pumped to the anoxic chamber in the biological part of the system. In this primary chamber, the heterotrophic bacteria's are moving the organic load from the sewage water. At the same time, the de-nitrification takes place. The secondary chamber will remove organic load and the nitrification will start in this stage. The third stage will perform the nitrification (see Fig.
$3)$.

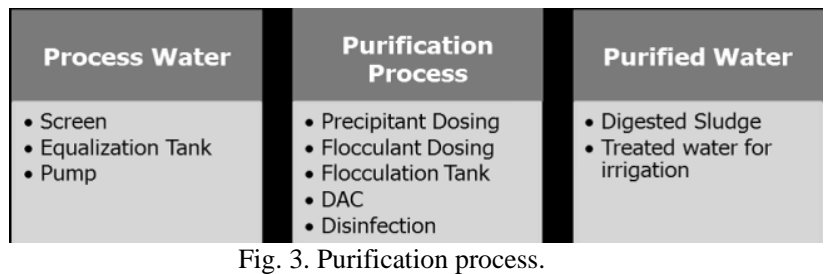

The resulting treated water will be used for irrigation and landscaping purposes. It is envisaged that this project will eliminate the need to send the sewage outside KOC for treatment and will instead be treated by Company itself in line with the Company's strategy of managing its own wastes. The effluent water from the STPs will be treated to meet the irrigation water standards and hence will reduce the need to use fresh water for irrigation water within the operational areas (see Fig. 4). 


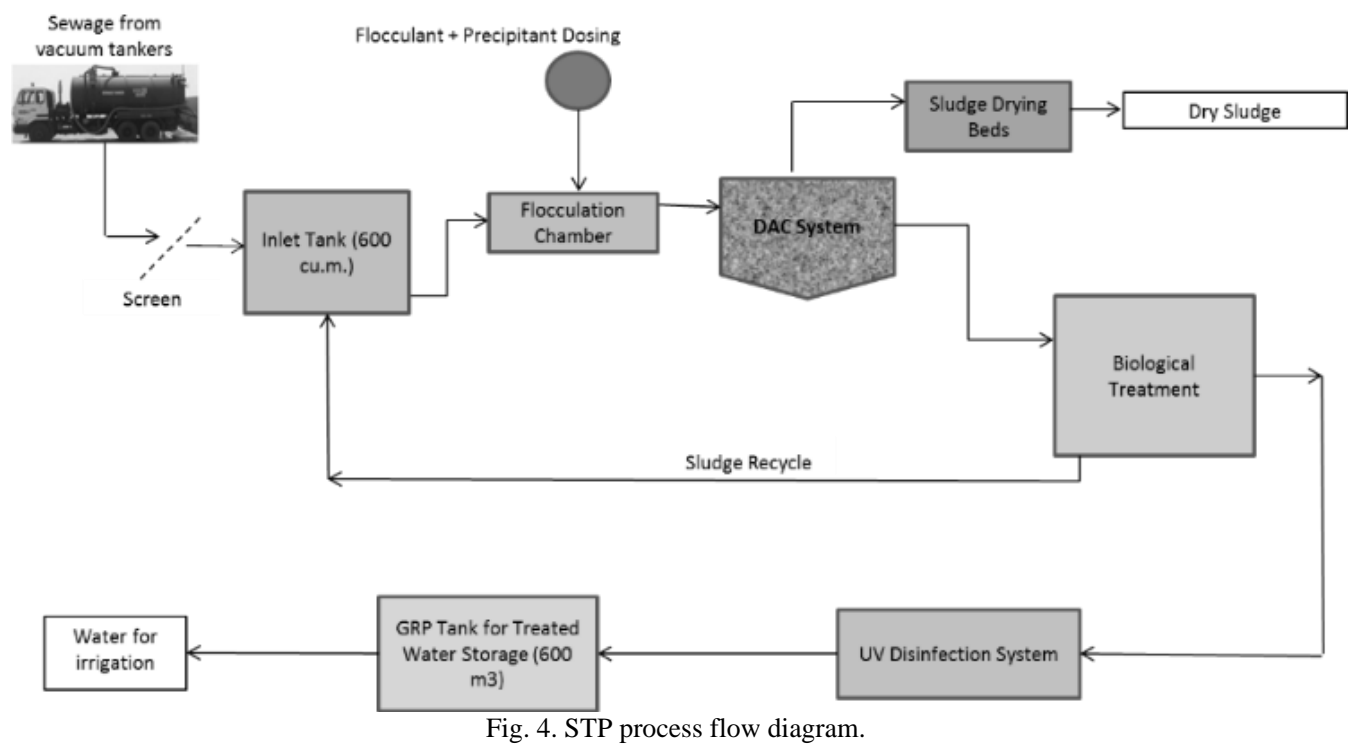

TABLE I: ANALYSIS RESULTS FOR TREATED SEWAGE BY ACCREDITED LAB

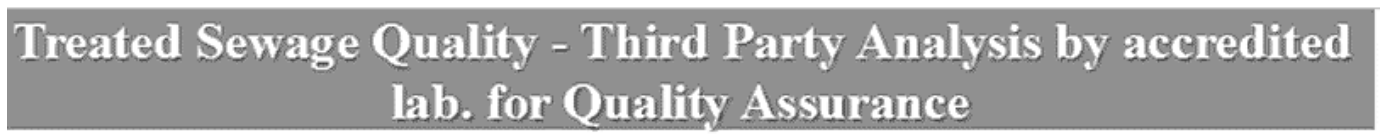

\begin{tabular}{|c|c|c|c|c|c|}
\hline SL.No. & Tests & Symbol & Units & KEPA Appendix (15) Limits & Analyzis Results from Napesco \\
\hline 1 & pH & $\mathrm{pH}$ & - & $6.5-8.5$ & 7 \\
\hline 2 & Biological orygen demand (from 2/8/2012) & BOD: & mgl & 20 & 3 \\
\hline 3 & Chemical oxygen demand & COD & mgl & 100 & 20 \\
\hline 4 & Oil \& Grease & O\&G & mg/ & 5 & 4 \\
\hline 5 & Total suspended solids & TSS & mgl & 15 & 2 \\
\hline 6 & Total Soluble Solids & TDS & mg/ & 1500 & 898 \\
\hline 7 & Phosphate & PO. & mg/ & 30 & $<0.01$ \\
\hline $\mathbf{s}$ & Ammonia & $\mathrm{NH}_{4}-\mathrm{N}$ & mg/ & 15 & 0.13 \\
\hline 9 & Nitrogen & $\mathbf{N}$ & mgl & 35 & 3.43 \\
\hline 10 & Total Recoverable Phenol & TRP & mg/ & 1 & $<0.01$ \\
\hline 11 & Fluorides & $\mathbf{F}$ & mg/ & 25 & 0.06 \\
\hline 12 & Sulides & $\mathbf{s}$ & $\mathrm{mg} / \mathrm{l}$ & 0.1 & $<0.04$ \\
\hline 13 & Chlorine & $\mathrm{Cl}_{8}$ & mgl & $0.5-1.0$ & $<0.04$ \\
\hline 14 & Dissolved Oxygen & DO & mg/ & $>2$ & 5.7 \\
\hline 15 & Hydrocarbon & HC & $\mathrm{mg} / \mathrm{l}$ & 5 & 2 \\
\hline 16 & Floatable & & mgl & Nil & Nil \\
\hline 17 & Aluminium & Al & mgl & 5 & $<0.05$ \\
\hline 18 & Arsenic & As & mgl & 0.1 & $<0.05$ \\
\hline 19 & Barium & $\mathbf{B a}$ & mgl & 2 & $<0.05$ \\
\hline 20 & Boron & B & mgl & 2 & $<0.05$ \\
\hline 21 & Cadmium & $\mathrm{Cd}$ & mg/ & 0.01 & $<0.01$ \\
\hline 22 & Chromium & $\mathrm{Cr}$ & $\mathrm{mg} / \mathrm{l}$ & 0.15 & $<0.05$ \\
\hline 23 & Nickel & $\mathbf{N i}$ & $\mathrm{mgl}$ & 0.2 & $<0.05$ \\
\hline 24 & Mercury & $\mathrm{Hg}$ & mg/ & 0.002 & $<0.001$ \\
\hline 25 & Cobalt & $C_{0}$ & mg/ & 0.2 & $<0.05$ \\
\hline 26 & Iron & Fe & mg/ & 5 & 0.237 \\
\hline 27 & Antimony & Sb & mg/ & - & $<0.05$ \\
\hline 28 & Copper & $\mathrm{Cu}$ & mg/ & 0.2 & $<0.05$ \\
\hline 29 & Manganese & Mn & $\mathrm{mg} /$ & 0.2 & 0.18 \\
\hline 30 & Zinc & $\mathbf{Z n}$ & $\mathrm{mgl}$ & 2 & $<0.05$ \\
\hline 31 & Lead & $\mathrm{Pb}$ & mg/ & 0.5 & 0.053 \\
\hline 32 & MPN of total coliform & MPN & MPN/100ml & 400 & 4 \\
\hline 33 & MPN of fecal coliform & MPPN & MPN/100ml & 20 & $<1.8$ \\
\hline 34 & Egg parasites & - & - & $<1$ & Nil \\
\hline 35 & Worm parasites & - & - & Nil & Nil \\
\hline
\end{tabular}

TABLE II: SEWAGE GENERATED IN SEKD

\begin{tabular}{|c|c|}
\hline Year & $\begin{array}{c}\text { Total Sew age } \\
\text { Generated in SEKD } \\
\text { Volume in m3 }\end{array}$ \\
\hline $\begin{array}{c}2009 \text { (Aug- } \\
\text { Dec) }\end{array}$ & 12487 \\
\hline 2010 & 37310 \\
\hline 2011 & 36665 \\
\hline 2012 & 33319 \\
\hline $\begin{array}{c}2013 \text { (January } \\
\text { - Nov.) }\end{array}$ & 52729 \\
\hline Total (m3) & 172510 \\
\hline
\end{tabular}

sewage) are collected in regular basis for the analysis by third party and the results are compared with K-EPA standards (Appendix 15) as per (see Table I) and if treated water come up from the STPs is meeting the KEPA limits then it will be transport through water tankers / pipe to various locations within the Company for use in horticulture.

The following chemicals (in very limited quantities) are used during the entire treatment process

- Ferric Chloride $\left(\mathrm{FeCl}_{3}\right)$

- Caustic Soda $(\mathrm{NaOH})$

- Polymer (Cataionic Flocculant) - Hydrex 6311
III. WASTEWATER ANAlysis AND MONITORING StRATEGY

Wastewater Samples from (Treated sewage and raw

\section{DATA AND TREND OF GENERATION}

A. Sewage Generated in SEKD (See Table II and Fig. 5) 


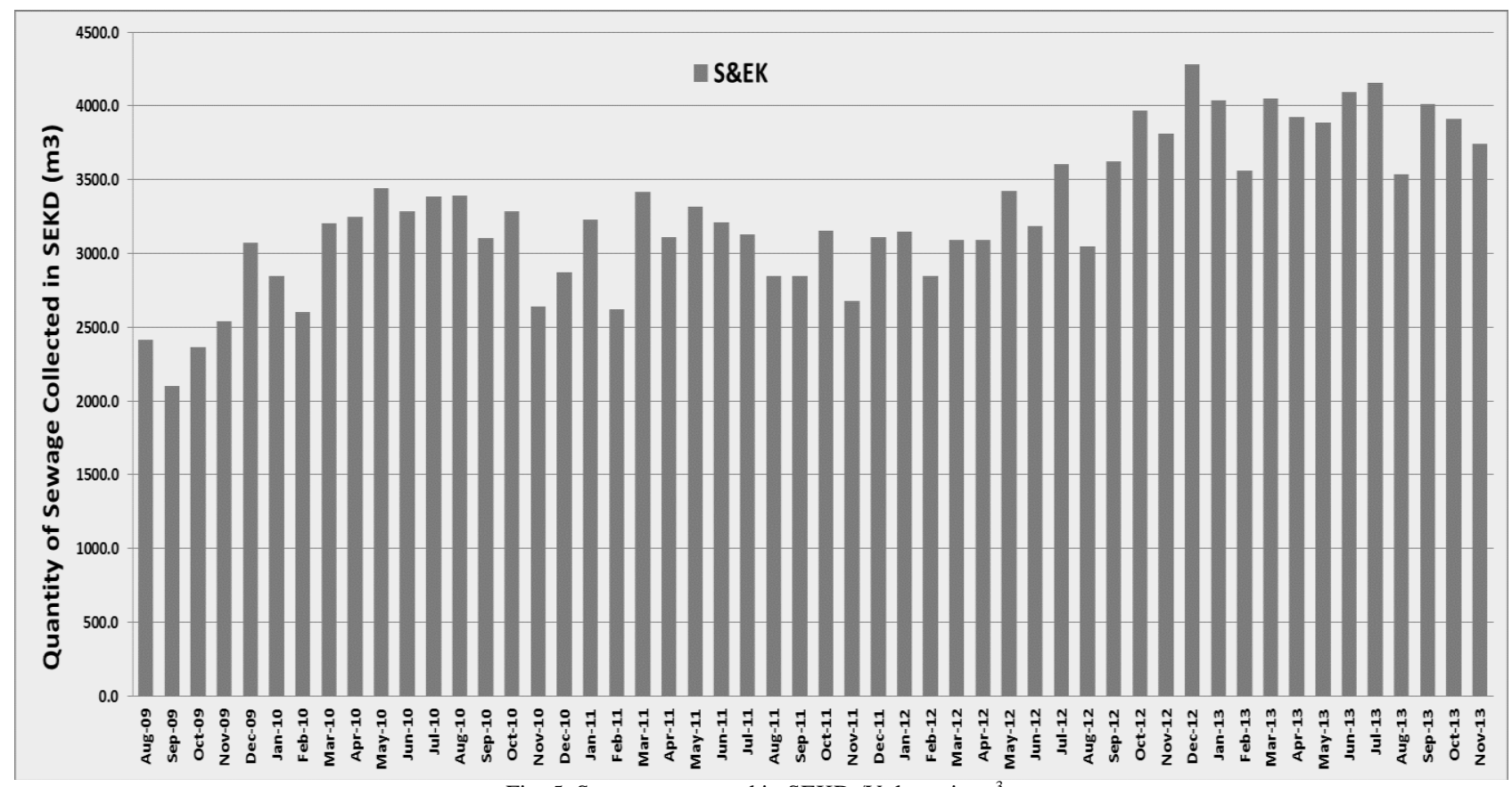

Fig. 5. Sewage generated in SEKD/Volume in $\mathrm{m}^{3}$.

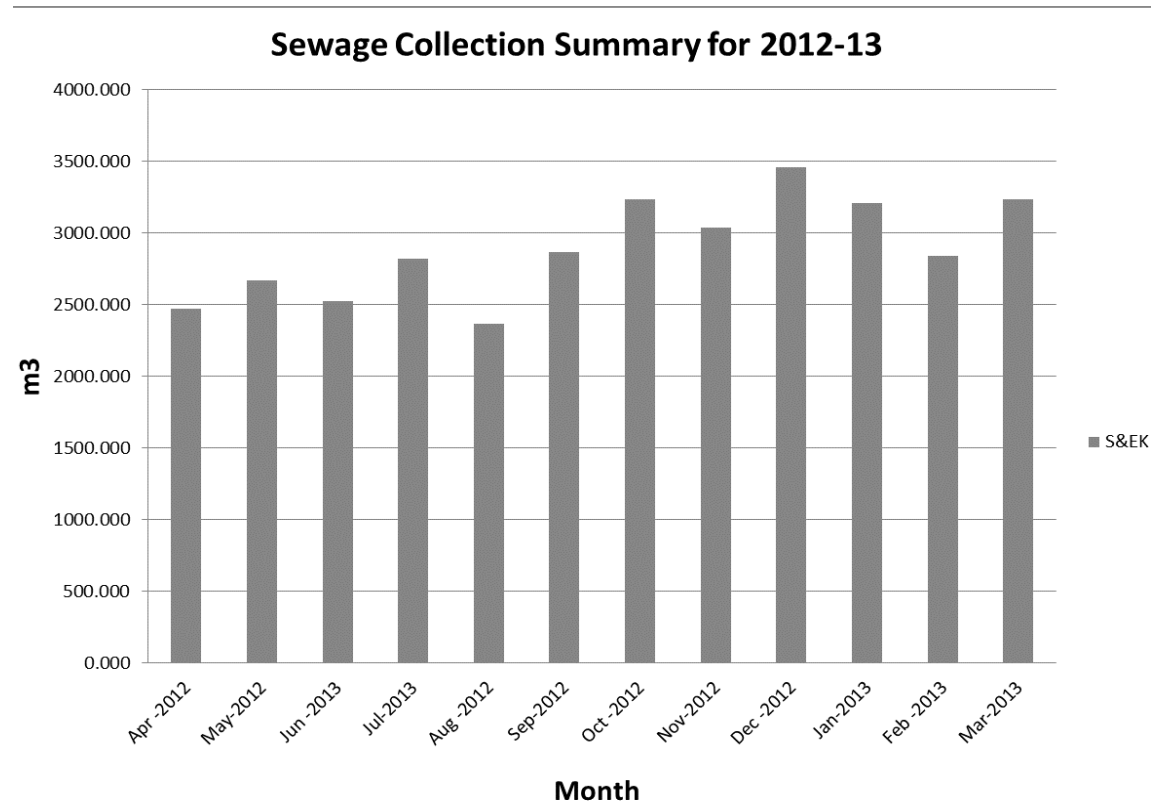

Fig. 6. Monthly sewage collection summary for the financial year 2012/2013.

The Chart Shows the Monthly Sewage Collection Summary for the Financial Year 2012/2013 for S\&EK Directorate (see Fig. 6).

Out of the total $91,208 \mathrm{~m}^{3}$ of sewage collected from throughout KOC facilities, around $40 \%\left(34,740 \mathrm{~m}^{3}\right)$ was collected from S\&EK itself. The sewage is treating in three sewage treatment plants within the Company's operational areas. Each plant having a capacity of $300 \mathrm{~m}^{3} /$ day and two of these sewage treatment plants are located in the S\&EK area. The treated water from these plants is the major source of brackish water for Company's irrigation purpose and is a step towards conserving fresh water in S\&EK directorate.

\section{ENERGY CONSERVATION AND BENEFITS FROM STPS}

\section{A. Energy Conservation}

Implementation and operation of the STPs shows the
Company's commitment towards environment, Sewage treatment plants are high-energy demand facilities. While reviewing the design of the STP process technology due care was taken to ensure proven record of accomplishment of the process in application worldwide and its suitability in the Kuwait environment. The process was selected for various advantages like low energy consumption, low chemical consumption, minimum odor emission, semi-automated process with minimal manual intervention, amenable to volume and quality fluctuation and consistent treated wastewater [5].

\section{B. Benefits of Wastewater Treated}

- Save money by recycling a portion of KOC wastewater use for irrigating Plantation / Landscaped / Garden Area.

- Reduce the impact on municipal sewage systems by installing a domestic treatment system.

- Steady increase of sewage quantity generated in 
Company's facilities due to increasing facility and manpower would have resulted in increased requirement of sewage tankers to transfer to the government STP. This would have resulted in direct increase of expenditure towards sewage transportation contract. Sending sewage to local KOC STP has resulted in reduction in trip length/time and managing higher volume with same tankers thereby managing/reducing cost.

- Energy and material cost of brackish water (ground water) pumping for irrigation.

- Fertilizer cost in landscaping by providing nutrient rich water.

- Expenditure towards cleanup and remediation of desert area subjected to contamination due to illegal sewage disposal.

- Expenditure towards material damage in accidents due to over-speeding and higher insure premium.

- Towards workers, vehicle and fuel required for on-site supervision of Contractor's vehicles.

- Enhancing Plantation in KOC area to combat desertification, reduce sand drifting, Contributing to action against Global warming and environmental improvement and motivation [6], [7].

\section{TREATED WATER USE IN KOC AREAS}

The treated water transported through water tankers to various locations (oasis) in the Company for irrigation, including Kuwait Oasis, Subaiya Oasis, Spirit of the Desert, Umm Al Aish Oases. The treated water is used within KOC in the oases, which act as a natural habitat for migratory birds, thus protecting the fauna in Kuwait (see Fig. 7).

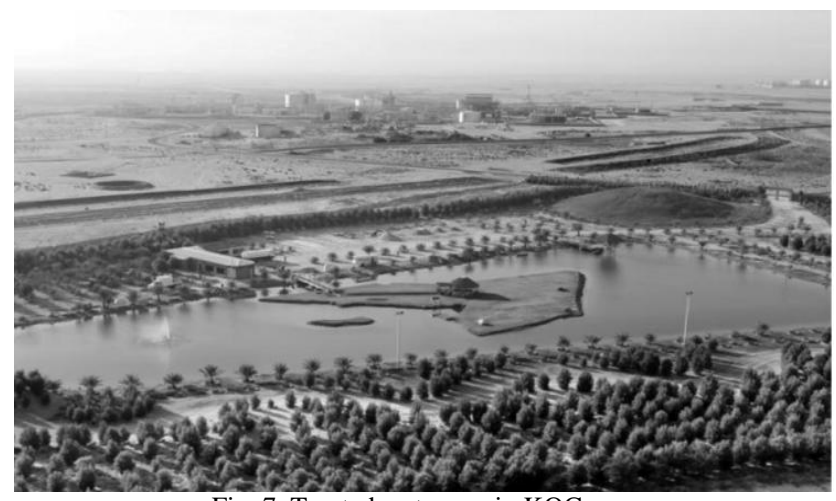

Fig. 7. Treated water use in $\mathrm{KOC}$ areas.

\section{PERFORMANCE AND Auditing OF WASTE MANAGEMENT PROGRAMME}

\section{A. Monthly HSE Performance and Service Record}

Monthly HSE performance report includes waste quantity data, which covers type $\&$ nature of waste, quantity generated in SEKD, activities of waste, quantity and disposal location. Service record contains sewage-generated location, cesspit ID, quantity of sewage collected, vehicle code, no. of trips from the location \& disposal location. Also the summary of sewage along with the graphs.

\section{B. Environmental Inspections}

HSE (S\&EK) Team have schedule to conduct weekly inspections to Contractor's site office and site to ensure smooth operation of the projects. Based on the observations, S\&EK team will follow-up the recommendations.

HSE inspections include the daily area supervisor tour. Such inspections should include assessment of STP facilities.

\section{CONCLUSION}

The treated water which leaves the sewage treatment system (STP) will be of the highest quality for renovated wastewater with less than $20 \mathrm{mg} / \mathrm{L} \mathrm{BOD}, 15 \mathrm{mg} / \mathrm{L}$ TSS, 35 $\mathrm{mg} / \mathrm{L}$ total $\mathrm{N}$, and $30 \mathrm{mg} / \mathrm{L}$ (as per KEPA Appendix 15 Limits ). It will be suitable for many applications throughout KOC facilities area, which are detailed in the Treated water use in KOC Areas section. The sewage treatment plant built by KOC has achieved real and quantifiable benefits in terms of the following:

Quantifiable benefits (from commencement date until end February 2013):

- Reduced environmental pollution.

$\mathrm{NO}_{\mathrm{X}}{ }^{-} \rightarrow 3,296 \mathrm{~kg}$

$\mathrm{CO}^{-} \rightarrow 1,011 \mathrm{~kg}$

- Reduced GHG emission (contributor to climate change / global warming). $\mathrm{CO}_{2}{ }^{-} \rightarrow 5,91,906 \mathrm{~kg}$

- Amount of sewage treated and recycled for irrigation $79,159 \mathrm{~m}^{3}$

(Conserving equivalent amount of brackish water)

- Conservation of fuel consumed in long distance travel of vacuum tankers to \& from NK, WK \& S\&EK to Umm Al-Hyman and Wafra (latter for the disposal of off-spec sewage) - 2,75,669 liters

- Reducing sewage load on Government STP which are already overloaded with municipal sewage from residential areas -Total KOC sewage treated $=79,159 \mathrm{~m}^{3}$

- Cost saving - 219,751 KD.

- Better compliance to wastewater management and reduce occurrences of illegal wastewater disposal.

- Reduced dependence on government STP to handle our waste.

- Reducing hazards associated with driving and possibility of spillage/ leaks of toxic sewage during long distance transport.

- Reducing load on existing government infrastructure pertaining to sewage receipt, treatment and disposal.

- Improved road safety due to reduction of heavy vehicular traffic.

- Enriching soil, landscaping and plants by providing nutrient rich treated sewage.

- Advantage of centralized STP over small sewage treatment packages.

- Impressing KOC's environmental commitment to Kuwait Environment Public Authority during visit to STP.

- A summary of quantified estimated environmental benefits (emissions reductions, fuel conservation etc.).

\section{REFERENCES}

[1] G. Lofrano and J. Brown. (2010). Wastewater management through the ages: Ahistory of mankind, Science of the Total Environment. [Online]. pp. 408. Available: http://www.elsevier.com/locate/scitotenv 
[2] J. M. Cavallini and L. EYoung. "Integrated Systems for the Treatment and Recycling of Wastewater in Latin America," IDRCPAHO/HEP/ CEPIS Agreement. Lima, 2002.

[3] W. P. Dunbar, Principles of Sewage Treatment, Charles Griffen \& Company, Ltd., London, England, 1908, pp. 158-1668.

[4] R. Gensch. "Productive sanitation: Increasing food security by reusing treated excreta and grey water in agriculture," Urban Agriculture Magazine, pp. 38-40, 2008.

[5] G. D. Rose, "Community-based technologies for domestic wastewater treatment and reuse," Options for Urban Agriculture. N. C. Division of Pollution Prevention and Environmental Assistance, CFP Report Series: Report 27, 1999.

[6] A. Fabiola, "Peru promotes treated wastewater reuse," Global Water Intelligence, November 2010.

[7] J. M. Cavallini and L. E. Young. "Reality and potential. integrated systems for the treatment and recycling of wastewater in Latin America," Urban Agriculture Magazine, vol. 8, pp. 18-19, 2002.

Khulood Yousef was born in Kuwait. She got the bachelor degree of science in chemical engineering from Kuwait University, Kuwait in 2000 with majoring in chemical engineering.

She has been working at Kuwait Oil Company (KOC) for 13 years in Health, Safety and Environment (HSE group), KOC.

She is a senior environmental engineer, Kuwait Oil Company, Kuwait from 2008 to present.

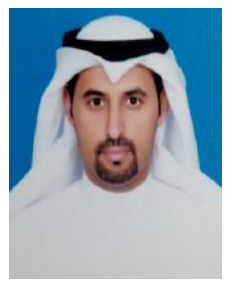

Soud Al-Mutairy was born in Kuwait on April 9, 1977. He got the bachelor degree of science in chemical engineering, Kuwait University, Kuwait in 2000 with majoring in chemical engineering.

$\mathrm{He}$ has been working at Kuwait Oil Company (KOC) for 13 years in HSE team of S\&EK, West Kuwait and North Kuwait Directorates

$\mathrm{He}$ is a senior environmental engineer in Kuwait Oil Company, Kuwait from 2008 to present; environmental engineer in Kuwait Oil Company, Kuwait from 2002 to 2008 environment engineer in the Environmental Department, Ministry of Oil, Kuwait from 2001 to 2002.

Mutairy is a member of ABS Consulting, American Society of Safety Engineers, Kuwait Chapter, Wataniya Env. Services Co., British Safety Council, Wataniya Env. Services Co., AMIDEAST, VISION Technology Center, Dale Carnegie Training, Gulf Consultants and Forth Valley College.

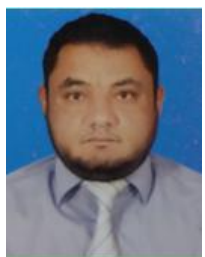

Haitham A. Fouzy was born in Kuwait on March 23 , 1969.

$\mathrm{He}$ got the $\mathrm{PhD}$ degree in environmental from $\mathrm{Dr}$ Bambu University Augrangabad- India in year 1999 with majoring in environmental science.

He has been working at National Petroleum Services Company for 7 years at Kuwait.

$\mathrm{He}$ has been an environmental engineering specialist in National Petroleum Services Company for 7 years in Kuwait; an environmental consultant in BDG Company, Kuwait from 2004 to 2007; and environmental engineer in Enviro Company, India from 1999 to 2004. He worked as a lecture assistant for the subjects of environmental pollution in $\mathrm{Dr}$ BAM.U University, India from 1996 to 1999.

Dr. Fouzy is a member of Wildlife Protection Society of India, New Delh since November 1999, India Outdoors Nature Club- Mumbai since January 2003 